\begin{abstract}
The article presents the history of theological and religious research conducted by the Institute of Fundamental Theology, Faculty of Theology at the John Paul II Catholic University of Lublin. In particular, it highlights the contribution of the Institute's employees to contemporary theological and religious research questions as well as presents their publication output. Their main research achievements include: the innovative association of the concept of religion and its theologically understood truthfulness with its genesis (the theory of the revelatory origin of religion); the original concept of theology of religion as an interdiscipline; the possibility to justify the plurality of religion de iure while maintaining the unique status of Christianity among the world religions; the close relationship between the theology of religion and fundamental theology in justifying this uniqueness, especially in discussions with representatives of the pluralist-relativistic theology of religion.
\end{abstract}

Keywords: the theology of religion; the concept of religion; the revelatory genesis of religion; the pluralism of religion; Christianity vs. non-Christian religions.

Theology of religion is the youngest discipline of religious studies which, apart from the religious sciences (empirical cognition) and philosophy of religion (speculative cognition), is the third possible way to study religion in the theological perspective, i.e. in the light of God's revelation. The formal origin of the theology of religion (terminus a quo) as an independent scientific discipline is universally dated to $1963,{ }^{1}$ although the history of

Dr. Hab. Ireneusz S. Ledwoń OFM, KUL Prof., Department of Religiology and Missiology, Institute of Fundamental Theology, CUL; mailing address: Katolicki Uniwersytet Lubelski Jana Pawła II, Al. Racławickie 14, 20-950 Lublin; e-mail: ledwon@kul.pl

${ }^{1}$ However, the forerunners of Catholic theology of religion are considered to be J.P. Steffen, O. Karrer, J. Daniélou, K. Rahner, and so the beginning of the discipline started with H.R. Schlettego's book Die Religionen als Thema der Theologie (Freiburg-Basel-Wien, 1963). The name of the discipline comes from the sub-title of the publication: Uberlegungen zu einer "Theologie der Religionen." However, the author writes that this concept goes back to the thoughts and creativity of its master, T. Ohma. 
theological research on religions dates back to patristic times. ${ }^{2} \mathrm{~A}$ real impulse for developing theology of religion was given by the doctrine of the Second Vatican Council, which perceived elements of truth, goodness and sanctity in non-Christian religions.

Even though research on religions conducted from the position of the history and ethnology of religion and comparative religions at the John Paul II Catholic University go back to the very beginnings of the university, theological and religious reflections at the Faculty of Theology of the Catholic University of Lublin began in the post-conciliar period, although sporadic cases of publications from the pre-conciliar period are found. ${ }^{3}$ The formal presence of theology of religion at the Faculty should be associated with its presence in the curriculum as a curricular lecture topic for $\mathrm{PhD}$ students specializing in fundamental theology and religious studies (led by Rev. Dr. M. Balwierz since 1986) and as a seminar in theology of religion led by Dr. Hab. I.S. Ledwoń OFM since 2009 in the Department of Theology of Religion, which under his leadership functioned in 2007-2016 in the Institute of Fundamental Theology.

Employees of the Faculty during this period included: Dr. Adam Wąs $\mathrm{SVD}^{4}$ and Rev. Dr. Hab. Krystian Kałuża. Previously, the issues concerning theology of religion were undertaken in the framework of the discipline of systematic theology in academic research, such as Christology, ecclesiology, and soteriology. As to publications, the name of the discipline first appeared in R. Łukaszyk, ${ }^{5}$ and next in texts by S. Kamiński in the field of methodo$\operatorname{logy}{ }^{6}{ }^{\mathrm{Z}}$. Zdybicka in philosophy of religion, ${ }^{7}$ A. Bronk, ${ }^{8}$ including the field

\footnotetext{
${ }^{2}$ Edward Kopeć, "Poglądy apologetów chrześcijańskich na poznanie Boga," Roczniki Teologiczno-Kanoniczne 4 (1957): 97-122; Ireneusz S. LEDwoŃ, “... i nie ma w żadnym innym zbawienia”. Wyjątkowy charakter chrześcijaństwa w teologii posoborowej (Lublin: Wydawnictwo KUL, 2006), 44-53.

${ }^{3}$ Edward Bulanda, "Wielość religii i właściwa płaszczyzna ich porównywania," Athenaeum Kaptańskie 306 (1960): 45-59.

${ }^{4}$ Rev. Adam Wąs, an eminent Islamologist, mainly published in the field of religious studies. He also conducted classes in his specialization in the fields of religious studies and mediteranistics as well as for doctoral students of fundamental theology.

5 "Historia zbawienia przed przyjściem Chrystusa," Zeszyty Naukowe KUL 11, no 2 (1968): 86-89.

6 "Metodologiczna osobliwość poznania teologicznego," Roczniki Filozoficzne 25, no 2 (1977): 81-96.

${ }^{7}$ Człowiek i religia (Lublin: Redakcja Wydawnictw KUL, 19843), 87: theology of religion examines "in the light of the revelation recognized by him (hence various theologies), the role of various religions in the work of salvation." This approach is very similar to the modern understanding of the discipline.

${ }^{8}$ Nauka wobec religii (Lublin: TN KUL, 1996); Podstawy nauk o religii (Lublin: TN KUL, 2003).
} 
of methodology, and finally in M. Rusecki in the field of theology of religion. ${ }^{9}$ Since the treatise De religione in genere historically belonged to apologetics, after our Chair was transformed into the Department of Fundamental Theology, the specialists in this later field understood the issue of religiology, whose framework includes the theology of religion.

In the Institute of Fundamental Theology (formerly Section) now belonging to the discussed discipline, work was sporadically undertaken by: B. Radomski (who created the concept of "religiology") ${ }^{10}$ and E. Bulanda (lecturer on comparative history of religion) ${ }^{11}$ apart from fundamental theology, the following also referred to theology of religion: E. Kopeć, ${ }^{12} \mathrm{~S}$. $\mathrm{Nagy}^{13}$ and K. Kaucha, ${ }^{14}$ including the already mentioned R. Łukaszyk. ${ }^{15}$

\footnotetext{
${ }^{9}$ Istota i geneza religii (Warszawa: Verbinum, 1989).

${ }^{10}$ Religiologia, nowa nauka teologiczna (Lublin, 1950) (mps); IDEM, Droga ku wszechstronnej metodzie badań nad fenomenem aktu wiary (Lublin, 1954) (mps). Radomski, however, considered the concept of "religiology" to have a different meaning. Today, it is basically a technical term for "religious studies." For Radomski, religiology was to help create an academic method for apologetics. It was to be composed of three stages: 1. Presenting the image of religious experiences of an individual or society (phenomenology of religious life) using the visualization method; 2. Extracting and relating the religious experience (appropriate religiological experience); 3. Correcting errors in concrete religious experiences (including viewpoints, the religiology-apologetics method) (LUKASZYK, "Pięćdziesięciolecie teologii fundamentalnej na Katolickim Uniwersytecie Lubelskim 1918-1968," Roczniki Teologiczno-Kanoniczne 15, no 2 (1968): 16). At the same time, as Łukaszyk writes, he created the concept of "vitality as an empirical science on the historical structures of the conscious life of an individual or social group, in whose framework he includes religious vitality, meaning an empirical science on religiousness" (ibidem).

11 "Misyjny dialog Kościoła dzisiejszego z religiami niechrześcijańskimi," in Kościót w świetle Soboru, ed. Henryk Bogacki, Stefan Moysa (Poznań: Księgarnia Św. Wojciecha, 1968), 409-466; "Żywotne siły religii świata," Ateneum Kaptańskie 364 (1969): 260-275; "Religie niechrześcijańskie w świetle teologii współczesnej," Homo Dei 41 (1972): 20-27; "Bóg i człowiek w duchowości różnych religii," Ateneum Kaptańskie 398 (1975): 384-396. Worth noting is the pre-conciliar text of this author, "Wielość religii i właściwa płaszczyzna ich porównywania," Ateneum Kaptańskie 306 (1960): 45-59.

12 "Poglądy apologetów chrześcijańskich na poznanie Boga," Roczniki Teologiczno-Kanoniczne 4 (1957): 97-122; "Co to jest religia?" Zeszyty Naukowe KUL 2 (1958): 73-85; "Kościół a religie niechrześcijańskie,” Zeszyty Naukowe KUL 9, no 4 (1966): 31-38; Teologia fundamentalna (Lublin: Redakcja Wydawnictw KUL, 1976), 17-43.

13 "Wprowadzenie do Deklaracji o stosunku Kościoła do religii niechrześcijańskich," in Sobór Watykański II. Konstytucje, dekrety, deklaracje (Poznań: Pallottinum, 1968), 327-333; "Dialog religii," Ateneum Kapłańskie 364, no 2 (1969): 276-287; “Kościół a sprawa zbawienia," Znak 468 (1994): 42-46.

14 "I nie ma w żadnym innym zbawienia [...]. Współczesne interpretacje jedyności i powszechności zbawczej Jezusa Chrystusa w kontekście wielości religii,” in Wokót deklaracji Dominus Iesus, ed. Marian Rusecki (Lublin: TN KUL, 2001), 143-167; "Pluralistyczno-relatywistyczna teologia religii J. Hicka i P.F. Knittera," in Chrześcijaństwo a religie. Dokument Międzynarodowej Komisji
} 
In a systematic way, theology of religion was and is also studied by fundamental theologians: M. Rusecki, I.S. Ledwoń and K. Kałuża. Beyond the Institute, CUL's theology of religion was also created by Lublin's dogmatists such as Krzysztof Góźdź ${ }^{16}$ and Janusz Lekan. ${ }^{17}$ A quite original approach to religion, its genesis and the significance of non-Christian religions in salvation history was proposed by Czesław Bartnik. ${ }^{18}$

In order to present the most important research achievements of the representatives of theology of religion at CUL's IFT, the following should be mentioned: 1. our original concept of theology of religion as a borderline discipline; 2. A theological concept of religion connected with its revelatory genesis; 3. Being based on justifying the fundamental theoretical paradigm of inclusivism, accepting the plurality of de iure religions, while maintaining the unique position of Christianity among other world religions.

\section{THE CONCEPT OF THE DISCIPLINE}

The very approach to the theology of religion at KUL was subject to a certain process of evolution. The first names for this field of studies come

Teologicznej. Tekst—komentarze-studia, ed. Ireneusz S. Ledwoń, Kazimierz Pek (Lublin-Warszawa: Wydawnictwo Księży Marianów, 1999), 123-135; “Zasada extra Ecclesiam salus nulla w świetle dokumentu Chrześcijaństwo a religie,” in Chrześcijaństwo a religie, 147-155.

15 "Problem przynależności do Kościoła Chrystusowego w ujęciu Konstytucji Lumen gentium Soboru Watykańskiego II," Roczniki Teologiczno-Kanoniczne 14, no 2 (1967): 61-81; "Religie niechrześcijańskie w ocenie teologii współczesnej," Ateneum Kapłańskie 364 (1969): 247-259; "Absolutny charakter chrześcijaństwa," in Encyklopedia Katolicka, vol. 1 (Lublin: TN KUL, 1973), 3739; "Objawienie kosmiczne jako pierwszy etap objawienia się Boga," Roczniki Teologiczno-Kanoniczne 24, no 4 (1977): 141-153; "Chrześcijaństwo. V. Stosunek do religii pozachrześcijańskich," in Encyklopedia Katolicka, vol. 3 (Lublin: TN KUL, 1979), 416-418.

${ }^{16}$ Teologia historii zbawienia wedtug Oscara Cullmanna (Lublin: Wydawnictwo KUL, 1996); "Jedyność i powszechność tajemnicy zbawczej Jezusa Chrystusa," in Wokót deklaracji Dominus Iesus, ed. Marian Rusecki (Lublin: TN KUL, 2001), 85-97; "Uniwersalizm zbawczy Jezusa Chrystusa," Sympozjum 1 (2001): 117-130.

${ }^{17}$ Jezus Chrystus Pośrednik zbawienia w hiszpańskiej teologii posoborowej (Lublin: Wydawnictwo KUL, 2010).

${ }^{18}$ Chrystus jako sens historii (Wrocław: Wydawnictwo Wrocławskiej Księgarni Archidiecezjalnej, 1987), 119-149; 314-329; IDEM, Eseje o historii zbawienia (Lublin: Standruk, 2002), 150-164, IDEM, Istota chrześcijaństwa (Lublin: Standruk, 2004), 15, 273-274; cf. Ireneusz S. LEDwoń, "Znaczenie religii pozachrześcijańskich w historii zbawienia" in In persona Christi. Księga na 80lecie Księdza Profesora Czestawa S. Bartnika, ed. Krzysztof Góźdź (Lublin: Wydawnictwo KUL, 2009) vol. 2, 591-600. 
from S. Kamiński, who called it "the theory of the salvific function of religion: its own, and the way its light shines on every other religion." 19 Thus, theology of religion was to bridge the gap between philosophy of religion and religious studies, making the revelation of religion understood in other religions as part of their culture.

On the other hand, M. Rusecki spoke about two types of theology of religion: in the narrower sense, as "a reflection on the salvific function of a particular religion in the light of normative documents from the revelation it knows," and in a broader sense, as a reflection on all religious realities (beyond religions) made in the light of Christian revelation. ${ }^{20}$ This approach, however, seems to break the unity of the discipline's subject matter. A. Bronk distinguishes two possible subjects of theology of religion: religion in general (theologia religionis) and certain historical religions (theologia religionum). ${ }^{21}$ This approach, in turn, is not enough to expose the theological (soteriological) significance of religious pluralism and the issue of the place of Christianity among other religions.

The latest approach to this discipline proposed at KUL's Institute of Fundamental Theology (by I.S. Ledwoń) understands the theology of religion as a borderline discipline (like fundamental theology) lying at the interface of historical and transcendental reality and empirical and theological cognition, whose starting point is data from religion and philosophy of religion, verifying it in the light of Christian revelation.

The theology of religion understood in this way includes two stages: the first is its theologia religionis, leading to specifying the theological concept of religion, and the second is based on the results of the previous stage, the theologia religionum, asking about the historical significance of the plurality of religions (de facto pluralism only, or de iure?) and their relationship to Christianity and the place of Christianity in a world of religions.

\footnotetext{
${ }^{19}$ Andrzej BRonK, Nauka wobec religii, 132; IDEM, Podstawy nauk o religii, 156.

${ }^{20}$ Marian RuSECKI, Istota i geneza religii (Lublin-Sandomierz: 19972), 41; IDEM, Traktat o religii (Warszawa: Verbinum, 2007), 55f.

${ }^{21}$ Nauka wobec religii [Science Towards Religion], 129; Podstawy nauk o religii [The Basics of Religious Studies], 151. According to this author, theology of religion can be understood either as an apologia of its own religion and its salvific function or as a critical assessment of the credibility (truthful claims) of other religions (Podstawy nauk o religii, 152).
} 


\section{THE CONCEPT OF RELIGION AND ITS GENESIS}

As a borderline discipline, the theology of religion comes from the data of philosophy of religion and religious studies. The first defines religion as a relational being, meaning a subject-object relationship between man and the Absolute. The term is strengthened by religious studies coming from the religious awareness of the followers of the vast majority of world religions, those who show their religiosity as an expression of the relationship to the highest and transcendent personal Reality (God).

Christian revelation confirms the relational nature of religion, enriching at the same time the image of man and God in this relationship with data on theology and theological anthropology. At this point, describing the nature of the religious relationship as salvific for man becomes important. It affects the understanding of the functions of religion, among which the salvific function is the most basic and axiologically important (in the theological perspective). However, it pre-supposes the necessity of God's grace and revelation, which transfers the issue of the concept of religion to the level of its genesis. The revealed data concerning both the nature of God as the Creator and the nature of man as a created being, as well as the motif itself (love) and the purpose of creation (human salvation), need God's revelation accepted by an act of faith, being free and intelligent (actus humanus), consenting to God's proposal presented in revelation to enter into a saving dialogue and the saving community of persons. The expression and consequence of this consent are religious acts on the part of man.

The purpose of creation and revelation, as well as the main goal of religion, in this case are identical: man's salvation. Thus, the revealed truth about the universal salvific will of God assumes the necessity for the universality of supernatural revelation and grace in the world of religion (K. Rahner). The universal revelatory basis for all religions would be Revelation through creation (Rusecki) ${ }^{22}$ and the active presence of God as the Creator in man (e.g. Bartnik, an immanent revelation based on religious experience). ${ }^{23}$ Since patristic times, in theology, there is also the concept of universal revelation (revelatio generalis), which is based on the Prologue of the fourth Gospel (Jn 1:9). ${ }^{24}$ God's revelation, being the condition for the

\footnotetext{
${ }^{22}$ Istota i geneza religii (Lublin-Sandomierz 1997²), 204-221; IDEM, Traktat o religii, 243-260.

${ }^{23}$ Czesław S. BARTNIK, Chrystus jako sens historii (Wrocław: Wydawnictwo Wrocławskiej Księgarni Archidiecezjalnej, 1987), 125f.

${ }^{24}$ LEDWOŃ, “... i nie ma $w$ żadnym innym zbawienia,” $469 f$.
} 
existence of religion, at the same time becomes the criterion of its truth, while in the theological sense and in contrast to religion, the true religion is considered to be the one that pursues its basic goal of salvation. ${ }^{25}$

The consequences of such an approach to the genesis of religion are the rejection of reductionist or naturalist theories of religion and questioning the concept of natural religions; all kinds of syncretism or sects also lose their status as religions, and thus become phenomena of purely human provenance (incidentally, being only natural). ${ }^{26}$ The revelational theory of the genesis of religion also enhances the conscious activity of man in salvation history, especially the individual (personal).

\section{THE THEOLOGICAL EVALUATION OF RELIGIOUS PLURALISM}

The realization of God's universal salvific will in religion and through religion plays a positive role in the history of salvation and is tantamount to accepting the plurality of de iure religion within the framework of the inclusivity paradigm. This pluralism (assigning God's provenance to religions), in contrast to the so-called de facto pluralism (the actual multitude of religions in the world), however, is not accepted by the Magisterium Ecclesiae because of the danger of relativizing Christianity and the alleged questioning of the only salvific mediation of Jesus Christ (cf. Dominus Iesus Declaration, No. 4).

It should be emphasized that inclusiveness, meaning Vatican II's recognizing only the existence of positive elements in religions (truth, goodness, sanctity), without accepting their role in achieving their believers' salvation, is in fact a hidden exclusivism, which also did not question granting God's grace beyond the Church's borders, nor the possibility of achieving salvation by non-Christians. However treated individually, they obtain salvation regardless of their religion or even despite or against it, thanks to living

\footnotetext{
${ }^{25}$ Marian RUSECKI, "Geneza religii,” in Religia w świecie wspótczesnym. Zarys problematyki religiologicznej, ed. Henryk Zimoń (Lublin: TN KUL, 2000), 71-88; IDEM, "Prawdziwość religii w świetle teologii," in Leksykon Teologii Fundamentalnej, ed. Marian Rusecki et al. (LublinKraków: Wydawnictwo M 2002), 963f.; LEDwoń, “... i nie ma w żadnym innym zbawienia,” 198f.; Marian RUSECKI, “Chrześcijaństwo pełnią zbawienia,” in Filozofować w kontekście teologii. Problem religii prawdziwej, ed. Piotr Moskal (Lublin: Wydawnictwo KUL, 2004), 51-93.

${ }^{26}$ Marian RUSECKI, "Naturalistyczne i ewolucjonistyczne teorie genezy religii," Ateneum Kapłańskie 468 (1987): 214-233; IDEM, Istota i geneza religii (Lublin-Sandomierz, 1997²), 93115; 161-187; 241-259; IDEM, Traktat o religii, 201-224.
} 
a life consistent with the voice of conscience. Meanwhile, there is no religious man whose conscience functions independently of his religion, in which this conscience was formed. The religious acts undertaken within it are an opportunity for God to grant them his grace. ${ }^{27}$

The inclusivist paradigm developed at the Institute of Fundamental Theology successfully avoids the relativization of both Christianity and Christ, thanks to the revealed origin of religion as the criterion of the true, meaning salvific, religion. This inclusiveness recognizes the absolute role of Jesus Christ in the history of salvation as the definitive Revealer of God and the only Mediator of all salvific grace. This grace is somehow granted "through" Christianity and the Church with which every grace is connected in a mysterious way (RMis 10). Christ gives to all religions from the fullness that is present in the Church, and therefore there is no salvation outside the Church, meaning without the Church. ${ }^{28}$

From the above, it follows that Christianity is not one of the many religions of the world, seen as one of the many equal paths to salvation. It is a religion that contains the fullness of the revealed truth and the fullness of salvation. However, we no longer apply Hegel's Christianity and the Troeltsch concept of absoluteness, ${ }^{29}$ which does not fully reflect the actual relationship between Christianity and the Church to the world, expressed in the spirit of inclusiveness (includo, Lat. to include). Absoluteness, which has an exceptionally exclusive tone, has been replaced by the notion of uniqueness, containing in itself fullness, superiority and universality. Uniqueness understood in this way, however, results from the absolute position of Jesus Christ in salvation history. The justification for his divine dignity is found in fundamental theology, whose research is used in theology of religion. First of all, in discussions with the pluralistic-relativist theology of religion, the theoretical and fundamental argumentation is found in no other theological

\footnotetext{
${ }^{27}$ LEDWoŃ, “... i nie ma $w$ żadnym innym zbawienia,” 489-491; IDEM, "Pluralizm religii de iure?” in Chrześcijaństwo pośród religii. Pluralizm czy nadrzędność? ed. Witosław J. Sztyk (Katowice: Studio Noa, 2009), 112-125; IDEM, "Wyjątkowy charakter chrześcijaństwa w kontekście pluralizmu religii," Studia Leopoliensia 4 (2011): 231-247.

${ }^{28}$ KAUCHA, "Zasada extra Ecclesiam salus nulla w świetle dokumentu Chrześcijaństwo a religie," 147-155; Ireneusz S. LEDwoŃ, "Extra Ecclesiam salus nulla?" Studia Salvatoriana Polonica 3 (2009): 57-74; IDEM, “... i nie ma w żadnym innym zbawienia,” 59-65; 511-521.

${ }^{29}$ Romuald ŁUKASZYK, "Absolutny charakter chrześcijaństwa," in Encyklopedia Katolicka, vol. 1 (Lublin: TN KUL, 1973), 37-39; LEDWOŃ, “... i nie ma w żadnym innym zbawienia,” 312 328; IDEM, "Chrześcijaństwo jako religia absolutna według G.W.F. Hegla,” Roczniki Teologiczne 53, no 9 (2006): 37-57.
} 
discipline. The analysis of foreign, mainly western theological and religious thought demonstrates that such an approach to the postulates of pluralists is proprium et specificum lublinense and results from the close cooperation between theology of religion and fundamental theology. ${ }^{30}$

As mentioned above, the uniqueness of Christianity is based on the absoluteness and unity of the Person of Jesus Christ that we accept in faith, but reasonably justified, and therefore making him credible. Taking a closer look at this issue, it should be added that this uniqueness is present on two levels: the historical (empirical) and theological (supernatural), analogous to the natures and two-plane structure of the Person of Jesus. In the historical perspective, this is the phenomenon of the Person of Jesus against the contemporary social and religious life and against the image of God (deity, gods) in religions in general, and in the context of the uniqueness and unrepeated transcendental claims by Jesus. In the theological perspective, this uniqueness is expressed in the fullness and definiteness of the revelation which he gave us, especially stressing the requirement of love which constitutes the essence of Christian life on a scale unheard of in any other religion. Next is the universality of his work of redemption and salvation, where the scandalum crucis stands in the center of this work, the phenomenon of the resurrection, and finally presenting Jesus as the fullness and purpose of all religious life (even if this goal is realized only in the eschaton). ${ }^{31}$

Regardless of what has been said so far about the overall vision of the discipline, within the theological and religious studies at the KUL Institute of Fundamental Theology, more detailed issues were and are being undertaken concerning: the history and methodological status of theology of religion, ${ }^{32}$ its sources, the concepts of religion, the history of Christianity's

\footnotetext{
${ }^{30}$ LEDWON, “... i nie ma $w$ żadnym innym zbawienia,” 346-458. In the discussion with the pluralistic theology of religion, it turned out that the liquidation of the chairs of apologetics and fundamental theology in the faculties of theology after the Second Vatican Council was premature and hasty.

${ }^{31}$ IDEM, "Jezus-Bóg, jakiego nie ma w żadnej religii," in O bogactwach Kościoła, ed. Marek Chojnacki, Józef Morawa, Andrzej A. Napiórkowski (Kraków: Wydawnictwo Salwator, 2014), 147-176; IDEM, "Jezus Chrystus, jedyny Zbawiciel świata, w świetle deklaracji Dominus Iesus," in Poezja i egzystencja. Księga jubileuszowa ku czci Profesora Józefa F. Ferta, ed. Wojciech Kruszewski, Dariusz Pachocki (Lublin: Wydawnictwo KUL, 2015), 687-702.

${ }^{32}$ IDEM, "Metodologiczny status teologii religii," Metodologia teologii. Studia Nauk Teologicznych PAN 2 (2007): 145-164; Krystian KAŁUŻA, "Teologia trynitarna jako podstawa chrześcijańskiej teologii religii?” in Teologia religii. Chrześcijański punkt widzenia, ed. Grzegorz Dziewulski (Łódź-Kraków: Wydawnictwo Księży Sercanów, 2007), 277-312; IDEM, Ein Mittler und viele Vermittlungen. Die Bedeutung des Religionsbegriffs für die christliche Theologie der Religionen
} 
relationship to non-Christian religions,$^{33}$ the salvific character of these religions, ${ }^{34}$ the possibility of God's revelation existing outside the biblical economy, the possibility of miracles in non-Christian religions,${ }^{35}$ knowledge of God in non-Christian religions, interreligious prayer and interreligious dialogue ${ }^{36}$ discussions with representatives of a pluralist-relativist theology of religion, ${ }^{37}$ contemporary approaches to the inclusive paradigm, also in Polish theology of religion, ${ }^{38}$ justifying the salvific unity and universality of the Person and work of Jesus Christ, ${ }^{39}$ and the salvific significance of the Church. ${ }^{40}$ Absolutely unprecedented in Poland are the critical studies on

(Frankfurt am Main: Peter Lang, 2011); IDEM, "Bóg bez granic. Perry’ego Schmidta-Leukela koncepcja teologii religii," Roczniki Teologii Fundamentalnej i Religiologii 4 (2012): 85-120.

${ }^{33}$ Ireneusz S. LEDwoŃ, “Teologiczny walor religii pozachrześcijańskich w nauczaniu papieża Jana Pawła II," Studia Teologiczno-Historyczne Ślaska Opolskiego” 22 (2002): 159-183; IDEM, "Kościół a religie pozachrześcijańskie," in Kościót w czasach Jana Pawła II, ed. Marian Rusecki et al. (Lublin: Wydawnictwo KUL, Wydawnictwo Gaudium, 2005), 173-193.

${ }^{34}$ Marian RUSECKI, "Elementy zbawcze w religiach pozachrześcijańskich," in Odkupienie a dialog międzyreligijny. Materiaty z sympozjum w Obrze 20-21 kwietnia 1998 roku, ed. Wojciech Kluj (Poznań: Uniwersytet im. A. Mickiewicza, Wydział Teologiczny, 1999), 21-61; Ireneusz S. LEDwoŃ, "Soteryczne znaczenie religii pozachrześcijańskich w chrześcijańskiej tradycji teologicznej i nauczaniu Kościoła," in Chrześcijaństwo pośród religii. Pluralizm czy nadrzędność?, 9-26; IDEM, "Zbawienie w religiach świata," in Wiarygodność chrześcijańskiego orędzia zbawienia, ed. Przemysław Artemiuk (Płock: Płocki Instytut Wydawniczy, 2015), 114-141.

${ }^{35}$ Marian RUSECKI, Problem cudu w religiach pozachrześcijańskich (Lublin: TN KUL, 2001).

${ }^{36}$ Ireneusz S. LEDwOŃ, "Modlitwa międzyreligijna w perspektywie dialogu doświadczenia religijnego," Roczniki Teologii Fundamentalnej i Religiologii 59 (2012): 143-161; Krystian KAŁUŻA, "Das multireligiöse Gebet als Wegweiser für den Dialog der Religionen," Roczniki Teologii Fundamentalnej i Religiologii 5 (2013): 117-138.

${ }^{37}$ KAUCHA, "Pluralistyczno-relatywistyczna teologia religii J. Hicka i P.F. Knittera"; Krystian KAŁUŻA, "Jeden Pośrednik i wiele pośrednictw. Teologia religii wobec zbawczych roszczeń religii pozachrześcijańskich," Roczniki Teologii Fundamentalnej i Religiologii 3 (2011): 117-149; Ireneusz S. LEDWOŃ, "Pluralistyczna teologia religii," in Teologia religii. Chrześcijański punkt widzenia, 35-54.

${ }^{38}$ Ireneusz S. LEDwoŃ, "Teologiczny walor religii niechrześcijańskich według Josepha Ratzingera," in Teologia fundamentalna w twórczości Josepha Ratzingera, ed. Krzysztof Kaucha, Jacenty Mastej (Lublin: Wydawnictwo KUL, 2017), 255-268; IDEM, "Ks. Romuald Łukaszyk jako prekursor polskiej teologii religii," in Pluralizm kulturowy i religijny wspótczesnego świata. Księga pamiątkowa dedykowana Księdzu Profesorowi Henrykowi Zimoniowi SVD w 70. rocznice urodzin, ed. Zdzisław Kupisiński, Stanisław Grodź (Lublin: Wydawnictwo KUL, 2010), 183-197; IDEM, "Badania teologicznoreligijne w Polsce," in Badania religiologiczne w Polsce, ed. Zdzisław Kupisiński (Lublin: Wydawnictwo KUL, 2011), 123-135.

${ }^{39}$ Ireneusz S. LEDwoŃ, "Pełnia i ostateczność objawienia w Jezusie Chrystusie," in Wokót deklaracji Dominus Iesus, 57-71; Krystian KaŁuŻa, "Odkupieni w Jezusie Chrystusie? Soteriologia chrześcijańska wobec wyzwań islamu," Nurt SVD 138, no 2 (2015): 29-55.

${ }^{40}$ Ireneusz S. LEDwoŃ, "Kościół a zbawienie w religiach,” in Wokót deklaracji Dominus Iesus, 127-142. 
comparative theology carried out by Rev. K. Kałuża (the publications and doctoral dissertations under his supervision). ${ }^{41}$ These issues are the topics of both the publications of our academic staff at the Institute of Fundamental Theology at the Catholic University of Lublin, as well as the master's or doctoral dissertations written under our supervision.

In this context, it is impossible to ignore the most important publications in the field of theology of religion, which appeared at the Faculty of Theology of the Catholic University of Lublin. These include the above-cited monumental Treatise on Religion by the late Rev. M. Rusecki (preceded by two editions of the essence and genesis of religion), commentaries on the Vatican documents on Christianity and Religions and Dominus Iesus, "... and there Is no Salvation in Another," an apology of the unique character of Christianity against the claims of pluralistic theologies of religion, and the published series Library of Theology of Religions. ${ }^{42}$

\section{BIBLIOGRAPHY}

BARTnik, Czesław S. Chrystus jako sens historii [Christ Gives History Meaning]. Wrocław: Wydawnictwo Wrocławskiej Księgarni Archidiecezjalnej, 1987.

BARTNIK, Czesław S. Eseje o historii zbawienia [Essays on Salvation History]. Lublin: Standruk, 2002. BARTNIK, Czesław S. Istota chrześcijaństwa [The Essence of Christianity]. Lublin: Standruk, 2004. Bronk, Andrzej. Nauka wobec religii [Science towards Religion]. Lublin: TN KUL, 1996.

Bronk, Andrzej. Podstawy nauk o religii [Basics of Religious Studies]. Lublin: TN KUL, 2003.

BulandA, Edward. "Bóg i człowiek w duchowości różnych religii" ["God and Man in the Spirituality of Various Religions”]. Ateneum Kaptańskie 398 (1975): 384-396.

Bulanda, Edward. "Misyjny dialog Kościoła dzisiejszego z religiami niechrześcijańskimi." In Kościót w świetle Soboru ["Missionary Dialogue of Today's Church with non-Christian Religions." In The Church in the Light of the Council], edited by Henryk Bogacki, Stefan Moysa, 409-466. Poznań: Księgarnia Św. Wojciecha, 1968.

\footnotetext{
${ }^{41}$ Bogdan WawrZASZEK, Teologia komparatywna $w$ ujęciu wybranych przedstawicieli teologii anglosaskiej i jej krytyka w świetle teologii katolickiej (Lublin, 2015) (mps); Krystian KAŁUŻA, “Teologia komparatywna. Geneza, opcje, szanse i problemy,” Roczniki Teologiczne 61, no 9 (2014): 43-92.

${ }^{42}$ Stary Testament a religie, ed. Ireneusz S. Ledwoń (Lublin: Wydawnictwo KUL, 2009); Nowy Testament a religie, ed. Ireneusz S. Ledwoń (Lublin: Wydawnictwo KUL, 2011); Wczesne chrześcijaństwo a religie, ed. Ireneusz S. Ledwoń, Mariusz Szram (Lublin: Wydawnictwo KUL, 2012); Nauczycielski Urząd Kościoła a religie, ed. Ireneusz S. Ledwoń, Piotr Królikowski (Lublin: Wydawnictwo KUL, 2015); Kościót Azji a religie, ed. Ireneusz S. Ledwoń (Lublin: Wydawnictwo KUL, 2018).
} 
BULANDA, Edward. "Religie niechrześcijańskie w świetle teologii współczesnej" ["Non-Christian Religions in the Light of Contemporary Theology"]. Homo Dei 41 (1972): 20-27.

Bulanda, Edward. "Wielość religii i właściwa płaszczyzna ich porównywania" ["The Multiplicity of Religions and their Proper Comparison"]. Ateneum Kaptańskie 306 (1960): 45-59.

Bulanda, Edward. "Żywotne siły religii świata" ["The Vital Powers of World Religions"]. Ateneum Kapłańskie 364 (1969): 260-275.

GóźDź, Krzysztof. "Jedyność i powszechność tajemnicy zbawczej Jezusa Chrystusa." In Wokót deklaracji "Dominus Iesus" ["The Uniqueness and Universality of the Salvific Mystery of Jesus Christ." In: Concerning the Declaration "Dominus Iesus"], edited by Marian Rusecki, 85-97. Lublin: TN KUL, 2001.

GóźDź, Krzysztof. "Uniwersalizm zbawczy Jezusa Chrystusa" ["The Salvific Universalism of Jesus Christ”]. Sympozjum 1 (2001): 117-130.

GóźDź, Krzysztof. Teologia historii zbawienia wedtug Oscara Cullmanna [Theology of Salvation History according to Oscar Cullmann]. Lublin: Wydawnictwo KUL, 1996.

KaŁuŻA, Krystian. "Bóg bez granic. Perry'ego Schmidta-Leukela koncepcja teologii religii” ["God without Boundaries. Perry Schmidt-Leukel's Concept of Theology of Religion"]. Roczniki Teologii Fundamentalnej i Religiologii 4 (2012): 85-120.

KAŁUŻA, Krystian. "Das multireligiöse Gebet als Wegweiser für den Dialog der Religionen." Roczniki Teologii Fundamentalnej i Religiologii 5 (2013): 117-138.

KaŁuŻA, Krystian. "Jeden Pośrednik i wiele pośrednictw. Teologia religii wobec zbawczych roszczeń religii pozachrześcijańskich" ["One Mediator and many Mediations. Theology of Religion towards the Salvific Claims of non-Christian Religions"]. Roczniki Teologii Fundamentalnej i Religiologii 3 (2011): 117-149.

KaŁuŻA, Krystian. “Odkupieni w Jezusie Chrystusie? Soteriologia chrześcijańska wobec wyzwań islamu" ["Redeemed in Jesus Christ? Christian Soteriology against the Challenges of Islam"]. Nurt SVD 138, no 2 (2015): 29-55.

KAŁUŻA, Krystian. "Teologia komparatywna. Geneza, opcje, szanse i problemy" ["Comparative Theology. Genesis, Options, Opportunities and Problems"]. Roczniki Teologiczne 61, no 9 (2014): 43-92.

KAŁUŻA, Krystian. “Teologia trynitarna jako podstawa chrześcijańskiej teologii religii?” In Teologia religii. Chrześcijański punkt widzenia ["Trinitarian theology as the Basis of Christian Theology of Religion?" In: Theology of Religion. The Christian Point of View], edited by Grzegorz Dziewulski, 277-312. Łódź-Kraków: Wydawnictwo Księży Sercanów, 2007.

KaŁUŻA, Krystian. Ein Mittler und viele Vermittlungen. Die Bedeutung des Religionsbegriffs für die christliche Theologie der Religionen. Frankfurt am Main: Peter Lang, 2011.

KAMIŃSKI, Stanisław. "Metodologiczna osobliwość poznania teologicznego" ["The Methodological Peculiarity of Theological Cognition"]. Roczniki Filozoficzne 25, no 2 (1977): 81-96.

KAUCHA, Krzysztof. "I nie ma w żadnym innym zbawienia [...]. Współczesne interpretacje jedyności i powszechności zbawczej Jezusa Chrystusa w kontekście wielości religii.” In Wokót deklaracji "Dominus Iesus" ["And there is no Salvation in Another [...]. Contemporary Interpretations of the Unity and Universality of the Salvation of Jesus Christ in the Context of the Multiplicity of Religions". In: Concerning the Declaration "Dominus Iesus"], edited by Marian Rusecki, 143-167. Lublin: TN KUL, 2001.

KAUCHA, Krzysztof. "Pluralistyczno-relatywistyczna teologia religii J. Hicka i P.F. Knittera" ["The Pluralistic-Relativistic Theology of Religion by J. Hick and P.F. Knitter"]. In Chrześcijaństwo a religie. Dokument Międzynarodowej Komisji Teologicznej. Tekst_komentarze-studia [Chri- 
stianity and Religions. Documents of the International Theological Commission], edited by Ireneusz S. Ledwoń, Kazimierz Pek, 123-135. Lublin-Warszawa: Wydawnictwo Księży Marianów, 1999.

KaUCHA, Krzysztof. "Zasada extra Ecclesiam salus nulla w świetle dokumentu Chrześcijaństwo a religie" ["The Principle of Extra Ecclesiam Salus Nulla in the Light of the Document Christianity and Religions”]. In Chrześcijaństwo a religie. Dokument Międzynarodowej Komisji Teologicznej. Tekst-komentarze - studia [Christianity and Religions. Documents of the International Theological Commission], edited by Ireneusz S. Ledwoń, Kazimierz Pek, 147155. Lublin-Warszawa: Wydawnictwo Księży Marianów, 1999.

Kopeć, Edward. “Co to jest religia?” [“What Is Religion?”]. Zeszyty Naukowe KUL 2 (1958): 73-85.

Kopeć, Edward. "Kościół a religie niechrześcijańskie” [“The Church and Non-Christian Religions"]. Zeszyty Naukowe KUL 9, no 4 (1966): 31-38.

KoPEĆ, Edward. "Poglądy apologetów chrześcijańskich na poznanie Boga" ["The views of Christian Apologists on Knowing God"]. Roczniki Teologiczno-Kanoniczne 4 (1957): 97-122.

Kopeć, Edward. Teologia fundamentalna [Fundamental Theology]. Lublin: Redakcja Wydawnictw KUL, 1976.

Kościót Azji a religie [The Asian Church and Religions], edited by Ireneusz S. Ledwoń. Lublin: Wydawnictwo KUL, 2018.

LEDWOŃ, Ireneusz S. “... i nie ma w żadnym innym zbawienia” Wyjątkowy charakter chrześcijaństwa w teologii posoborowej [“... and there Is no Salvation in Another.” The Exceptional Nature of Christianity in Post-Conciliar Theology]. Lublin: Wydawnictwo KUL, 2006.

LEDwoń, Ireneusz S. "Badania teologicznoreligijne w Polsce" ["Theological and Religious Research in Poland"]. In Badania religiologiczne w Polsce [Religiology Research in Poland], edited by Zdzisław Kupisiński, 123-135. Lublin: Wydawnictwo KUL, 2011.

LEDWoŃ, Ireneusz S. "Chrześcijaństwo jako religia absolutna według G.W.F. Hegla” [“Christianity an Absolute Religion according to G.W.F. Hegel”]. Roczniki Teologiczne 53, no 9 (2006): 37-57.

LEDwoŃ, Ireneusz S. “Extra Ecclesiam salus nulla?” Studia Salvatoriana Polonica 3 (2009): 57-74.

LEDwoŃ, Ireneusz S. "Geneza religii pozachrześcijańskich w ujęciu Soboru Watykańskiego II" ["The Genesis of non-Christian Religions according to the Second Vatican Council"]. Roczniki Teologiczne 47, no 9 (2000): 71-91.

LEDwoń, Ireneusz S. “Jezus Chrystus, jedyny Zbawiciel świata, w świetle deklaracji Dominus Iesus" ["Jesus Christ, the only Savior of the World in the Light of the Declaration Dominus Iesus”]. In Poezja i egzystencja. Księga jubileuszowa ku czci Profesora Józefa F. Ferta [Poetry and Existence. A Jubilee Book in Honor of Professor Józef F. Fert], edited by Wojciech Kruszewski, Dariusz Pachocki, 687-702. Lublin: Wydawnictwo KUL, 2015.

LEDwoń, Ireneusz S. "Jezus-Bóg, jakiego nie ma w żadnej religii” [“Jesus: God Who Is not Present in Any Other Religion”]. In O bogactwach Kościoła [On the Church's Richness], edited by Marek Chojnacki, Józef Morawa, Andrzej A. Napiórkowski, 147-176. Kraków: Wydawnictwo Salwator, 2014.

LEDwoń, Ireneusz S. "Kościół a religie pozachrześcijańskie” [“The Church and non-Christian Religions"]. In Kościót w czasach Jana Pawta II [The Church in the Times of John Paul II], edited by Marian Rusecki, Krzysztof Kaucha, Jacenty Mastej, 173-193. Lublin: Wydawnictwo KUL, Wydawnictwo Gaudium, 2005.

LEDwoŃ, Ireneusz S. "Kościół a zbawienie w religiach" ["Church and Salvation in Religions"]. In Wokót deklaracji "Dominus Iesus" [Concerning the Declaration "Dominus Iesus"], edited by Marian Rusecki, 127-142. Lublin: TN KUL, 2001. 
LEDWOŃ, Ireneusz S. "Ks. Romuald Łukaszyk jako prekursor polskiej teologii religii" ["Rev. Romuald Łukaszyk as a Forerunner of Polish Theology of Religion"]. In Pluralizm kulturowy i religijny wspótczesnego świata. Księga pamiątkowa dedykowana Księdzu Profesorowi Henrykowi Zimoniowi SVD w 70. rocznice urodzin [Cultural and Religious Pluralism of the Modern World. A Commemorative Book Dedicated to Rev. Professor Henryk Zimon SVD on his $70^{\text {th }}$ Birthday], edited by Zdzisław Kupisiński, Stanisław Grodź, 183-197. Lublin: Wydawnictwo KUL, 2010.

LEDWOŃ, Ireneusz S. "Metodologiczny status teologii religii" ["The Methodological Status of Theology of Religion"]. In Metodologia teologii [Methodology of Theology]. Studia Nauk Teologicznych PAN 2 (2007): 145-164.

LEDWOŃ, Ireneusz S. "Modlitwa międzyreligijna w perspektywie dialogu doświadczenia religijnego" ["Interreligious Prayer in the Perspective of Dialogue on Religious Experiences"]. Roczniki Teologii Fundamentalnej i Religiologii 59 (2012): 143-161.

LeDwoń, Ireneusz S. "Pełnia i ostateczność objawienia w Jezusie Chrystusie" ["The Full and Final Revelation in Jesus Christ"]. In Wokót deklaracji "Dominus Iesus" [Concerning the Declaration "Dominus Iesus"], edited by Marian Rusecki, 57-71. Lublin: TN KUL, 2001.

LEDwoŃ, Ireneusz S. "Pluralistyczna teologia religii" ["The Pluralistic Theology of Religion"]. In Teologia religii. Chrześcijański punkt widzenia [Theology of Religion. The Christian Point of View], edited by Grzegorz Dziewulski, 35-54. Łódź-Kraków: Wydawnictwo Księży Sercanów, 2007.

LEDwoŃ, Ireneusz S. "Pluralizm religii de iure?" ["Pluralism of religion de iure"]. In Chrześcijaństwo pośród religii. Pluralizm czy nadrzędność? [Christianity among religions. Pluralism or Superiority], edited by Witosław J. Sztyk, 112-125. Katowice: Studio Noa, 2009.

LEDWOŃ, Ireneusz S. "Soteryczne znaczenie religii pozachrześcijańskich w chrześcijańskiej tradycji teologicznej i nauczaniu Kościoła" ["The Soteric Meaning of non-Christian Religions in the Christian Theological Tradition and the Teaching of the Church"]. In Chrześcijaństwo pośród religii. Pluralizm czy nadrzędność? [Christianity in the midst of Religion. Pluralism or Superiority?], edited by Witosław J. Sztyk, 9-26. Katowice: Studio Noa, 2009.

LEDWOŃ, Ireneusz S. "Teologiczny walor religii niechrześcijańskich według Josepha Ratzingera" ["The Theological Value of non-Christian Religions according to Joseph Ratzinger"]. In Teologia fundamentalna $w$ twórczości Josepha Ratzingera [Fundamental Theology in the Works of Joseph Ratzinger], edited by Krzysztof Kaucha, Jacenty Mastej, 255-268. Lublin: Wydawnictwo KUL, 2017.

LEDWOŃ, Ireneusz S. “Teologiczny walor religii pozachrześcijańskich w nauczaniu papieża Jana Pawła II" ["The Theological Value of non-Christian Religions in the Teaching of Pope John Paul II”]. Studia Teologiczno-Historyczne Śląska Opolskiego 22 (2002): 159-183.

LEDWOŃ, Ireneusz S. "Wyjątkowy charakter chrześcijaństwa w kontekście pluralizm religii" ["The Unique Character of Christianity in the Context of the Pluralism of Religions"]. Studia Leopoliensia 4 (2011): 231-247.

LEDWOŃ, Ireneusz S. "Wyjątkowy charakter chrześcijaństwa" ["The Unique Character of Christianity"]. In Uniwersalizm chrześcijaństwa a pluralizm religii [Universalism of Christianity and Pluralism of Religion], edited by Stanisław Budzik, Zdzisław Kijas, 72-106. Tarnów: Biblos, 2000.

LEDwoŃ, Ireneusz S. "Zbawienie w religiach świata" ["Salvation in the Religions of the World"]. In Wiarygodność chrześcijańskiego orędzia zbawienia [The Credibility of the Christian Message of Salvation], edited by Przemysław Artemiuk, 114-141. Płock: Płocki Instytut Wydawniczy, 2015. 
LEDwoŃ, Ireneusz S. "Znaczenie religii pozachrześcijańskich w historii zbawienia" ["The Importance of non-Christian Religions in the History of Salvation"]. In In persona Christi. Ksiega na 80-lecie Księdza Profesora Czestawa S. Bartnika [A Book for Father Czesław S. Bartnik’s $80^{\text {th }}$ Anniversary], edited by Krzysztof Góźdź, vol. 2, 591-600. Lublin: Wydawnictwo KUL, 2009.

LeKan, Janusz. Jezus Chrystus Pośrednik zbawienia w hiszpańskiej teologii posoborowej [Jesus Christ. Mediator of Salvation in Spanish Post-Conciliar Theology]. Lublin: Wydawnictwo KUL, 2010.

ŁUKASZYK, Romuald. "Absolutny charakter chrześcijaństwa" ["The Absolute Character of Christianity.”] In Encyklopedia Katolicka, vol. 1, 37-39. Lublin: TN KUL, 1973.

ŁUKASZYK, Romuald. "Chrześcijaństwo. V. Stosunek do religii pozachrześcijańskich" ["Christianity. V. Relations with non-Christian Religions”]. In Encyklopedia Katolicka, vol. 3, 416418. Lublin: TN KUL, 1979.

ŁUKASZYK, Romuald. "Historia zbawienia przed przyjściem Chrystusa" ["Salvation History before the Coming of Christ"]. Zeszyty Naukowe KUL 11, no 2 (1968): 86-89.

ŁUKASZYK, Romuald. "Objawienie kosmiczne jako pierwszy etap objawienia się Boga" ["Cosmic Revelation as the First Stage of God's Revelation"]. Roczniki Teologiczno-Kanoniczne 24, no 4 (1977): 141-153.

ŁUKASZYK, Romuald. "Pięćdziesięciolecie teologii fundamentalnej na Katolickim Uniwersytecie Lubelskim 1918-1968" ["Fifty Years of Fundamental Theology at the Catholic University of Lublin 1918-1968”]. Roczniki Teologiczno-Kanoniczne 15, no 2 (1968): 5-53.

ŁUKASZYK, Romuald. "Problem przynależności do Kościoła Chrystusowego w ujęciu Konstytucji Lumen gentium Soboru Watykańskiego II" ["The Issue of Belonging to the Church of Christ in Terms of the Constitution Lumen gentium of the Second Vatican Council']. Roczniki Teologiczno-Kanoniczne 14, no 2 (1967): 61-81.

ŁUKASZYK, Romuald. "Religie niechrześcijańskie w ocenie teologii współczesnej” ["Non-Christian Religions in the Evaluation of Contemporary Theology."] Ateneum Kaptańskie 364 (1969): 247-259.

NAGY, Stanisław. "Dialog religii" ["Religious Dialogue”]. Ateneum Kapłańskie 364 (1969): 276-287.

NAGY, Stanisław. "Kościół a sprawa zbawienia” [“The Church and the Matter of Salvation.”] Znak 468 (1994): 42-46.

NAGY, Stanisław. "Wprowadzenie do Deklaracji o stosunku Kościoła do religii niechrześcijańskich" ["Introduction to the Declaration on the Relationship of the Church to Non-Christian Religions”]. In Sobór Watykański II. Konstytucje, dekrety, deklaracje [Vatican Council II. Constitutions, decrees, declarations], 327-333. Poznań: Pallottinum, 1968.

Nauczycielski Urzad Kościoła a religie [The Teaching Office of the Church and Religions], edited by Ireneusz S. Ledwoń, Piotr Królikowski. Lublin: Wydawnictwo KUL, 2015.

Nowy Testament a religie [The New Testament and Religions], edited by Ireneusz S. Ledwoń. Lublin: Wydawnictwo KUL, 2011.

RADOMSKI, Bolesław. Droga ku wszechstronnej metodzie badań nad fenomenem aktu wiary [The Road to the Comprehensive Method of Research on the Phenomenon of the Act of Faith]. Lublin, 1954 (mps).

RADOMSKI, Bolesław. Religiologia, nowa nauka teologiczna [Religiology, the New Theological Science]. Lublin, 1950 (mps).

RUSECKI, Marian. "Chrześcijańska interpretacja genezy religii” ["The Christian Interpretation of the Genesis of Religion”]. Ateneum Kapłańskie 468 (1987): 234-252. 
RUSECKI, Marian. "Chrześcijaństwo a religie. Analiza krytyczna" ["Christianity and Religions. A Critical Analysis"]. In Chrześcijaństwo a religie. Dokument Międzynarodowej Komisji Teologicznej. Tekst-komentarze-studia [Christianity and Religions. Documents of the International Theological Commission. Text-Comments-Studies], edited by Ireneusz S. Ledwoń, Kazimierz Pek, 69-80. Lublin-Warszawa: Wydawnictwo Księży Marianów, 1999.

RUSECKI, Marian. “Chrześcijaństwo pełnią zbawienia” [“Christianity Is Complete Salvation”] In Filozofować w kontekście teologii. Problem religii prawdziwej [To philosophize in the Context of Theology. The Problem of True Religion], edited by Piotr Moskal, 51-93. Lublin: Wydawnictwo KUL, 2004.

RUSECKI, Marian. "Elementy zbawcze w religiach pozachrześcijańskich.” In Odkupienie a dialog międzyreligijny. Materiaty z sympozjum w Obrze 20-21 kwietnia 1998 roku ["Elements of Salvation in non-Christian Religions." In: Redemption and Inter-Religious Dialogue], edited by Wojciech Kluj, 21-61. Poznań: Uniwersytet im. A. Mickiewicza, Wydział Teologiczny, 1999.

RUSECKI, Marian. "Geneza religii” ["The Genesis of Religion”] In Religia w świecie wspótczesnym. Zarys problematyki religiologicznej [Religion in the Modern World. Outline of Religiological Issues], edited by Henryk Zimoń, 71-88. Lublin: TN KUL, 2000.

RUSECKI, Marian. "Naturalistyczne i ewolucjonistyczne teorie genezy religii" ["Naturalistic and Evolutionary Theories on the Genesis of Religion”]. Ateneum Kaptańskie 468 (1987): 214-233.

Rusecki, Marian. "Prawdziwość religii w świetle teologii" ["The Truth of Religion in the Light of Theology"]. In Leksykon Teologii Fundamentalnej [Lexicon of Fundamental Theology], edited by Marian Rusecki, Krzysztof Kaucha, Ireneusz S. Ledwoń, Jacenty Mastej, 963-964. Lublin- Kraków: Wydawnictwo M, 2002.

RUSECKI, Marian. Istota i geneza religii [The Essence and Genesis of Religion]. Warszawa: Verbinum, 1989; Lublin-Sandomierz: Wydawnictwo Diecezjalne, 1997².

RuseCKI, Marian. Problem cudu w religiach pozachrześcijańskich [The Issue of Miracles in nonChristian Religions]. Lublin: TN KUL, 2001.

RUSECKI, Marian. Traktat o religii [Treatise on Religion]. Warszawa: Verbinum, 2007.

SCHLETtE, Heinz Robert. Die Religionen als Thema der Theologie. Freiburg-Basel-Wien: Herder, 1963. Stary Testament a religie [The Old Testament and Religions], edited by Ireneusz S. Ledwoń. Lublin: Wydawnictwo KUL, 2009.

WAWRZASZEK, Bogdan. Teologia komparatywna w ujęciu wybranych przedstawicieli teologii anglosaskiej i jej krytyka w świetle teologii katolickiej [Comparative Theology from the Perspective of Selected Representatives of Anglo-Saxon Theology and its Criticism in the Light of Catholic Theology]. Lublin, 2015 (mps).

Wczesne chrześcijaństwo a religie [Early Christianity and Religions], edited by Ireneusz S. Ledwoń, Mariusz Szram. Lublin: Wydawnictwo KUL, 2012.

ZDYBICKA, Zofia. Człowiek i religia [Man and religion]. Lublin: Redakcja Wydawnictw KUL, $1984^{3}$.

Translated by Jan Kobytecki

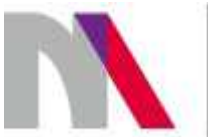

The preparation of the English version of Roczniki Teologiczne (Annals of Theology) and its publication in electronic databases was financed under contract no. 836/P-DUN/2018 from the resources of the Minister of Science and Higher Education for the popularization of science. 